\title{
PENGARUH TEKS SANGKALAN TERHADAP PENCAPAIAN KONSEP SISWA TENTANG HUKUM PERTAMA DAN KETIGA NEWTON
}

\author{
Ketut Suma \\ Jurusan Pendidikan Fisika, \\ Universitas Pendidikan Ganesha, Indonesia \\ E-mail: sumaketut@ymail.com
}

\begin{abstract}
Abstrak
Tujuan penelitian ini adalah menguji pengaruh pengajaran yang menggunakan teks-teks sangkalan terhadap pencapaian konsep siswa tentang hukum I dan III Newton, dibandingkan dengan pengajaran yang menggunakan teks ekspositori. Sampel penelitian ini terdiri atas 73 orangsiswa kelompok eksperimen dan 85 orang kelompok kontrol. Selama pengajaran hukum I dan III Newton pengajaran menggunakan teks sangkalan diberikan kepada kelompok eksperimen, sedangkan pengajaran menggunakan teks ekspositori diberikan pada kelompok kontrol. Data yang dikumpulkan dalam penelitian ini adalah gain skor ternormalisasi (g) pencapaian konsep siswa.Data dikumpulkan dengan tes penguasaan konsep dengan indek reliablitas $r=0,65$ dan dianalisis dengan Uji Man Whitney. Hasil penelitian menunjukkan bahwa (1) rata-rata gain skor ternormalisasi $(\bar{g})$ siswa kelompok eksperimen adalah 0,54 dengan $\mathrm{SD}=0,128$ yang termasuk dalamkategori sedang, sedangkan $\bar{g}$ kelompok kontrol adalah0,16 dengan $\mathrm{SD}=0,104$, yang termasuk dalam kategori rendah. (2) persentase kelompok eksperimen dan kelompok kontrol yang memiliki konsep ilmiah masing-masing naik rata-rata 39,45\%dan 12,65\%. (2) uji Man Withney menunjukkan bahwa terdapat perbedaan pencapaian konsep antara siswa kelompok eksperimen dan kelompok kontrol.
\end{abstract}

Kata Kunci: teks sangkalan, teks ekspositori, dan pencapaian konsep

\begin{abstract}
The objective of this study was to examine the effects of instruction by using refutation text on students' concept achievement about the first and the third Newton's law of motion as compared with instruction by using expository text. The sample of this study consisted of 73 students of experimental group and 85 students of control group. During teaching the topic of the first and the third Newton law, instruction by using refutation text was applied in the experimental group whereas instruction by using expository text was followed in the control group. The data collected in this study were normalized gain score (g) of student's concept achievement. Data collected by using a concept achievement test with reliability index $r=0,65$ dan was analyzed by using Mann Whitney Test.The result showed
\end{abstract}


that (1) the mean of $\bar{g}$ of experimental group was 0.54 , with $\mathrm{SD}=0.128$, that was on the medium level, while the mean of $\bar{g}$ of control group was 0.16 with $\mathrm{SD}=0.104$, that was in low level; (2) The percentage of experimental and control group who have a scientific concept each of rose an average of $39.45 \%$ and $12.65 \%$.The Man Whitney test indicated there was the difference of concept achievement between the experimental group and the control group. The mean $\bar{g}$ ofexperimental group was higher than control group.

Keywords: refutation text, expository text, concept achievement

\section{PENDAHULUAN}

Sampai saat ini masalah kualitas pendidikan di Indonesia, khususnya pendidikan sains masih menjadi keprihatinan para pendidik. Survey yang dilakukan oleh TIMSS (2007) menunjukkan bahwa literasi sains Indonesia berada pada urutan ke 35 dari 49 negera yang disurvey dengan skor capaian 433, dan masih di bawah ratarata skor internasional yaitu 500 . Rendahnya kualitas pendidikan sains di Indonesia juga ditunjukkan oleh studi yang dilakukan oleh the Programme for International Student Assessment (PISA) tahun 2006 yang menempatkan literasi sains Indonesia pada peringkat ke 50 dari 57 negara yang disurvey dengan skor rata-rata sains adalah 391, masih di bawah rata-rata internasional yaitu 498. Prestasi ini masih di bawah Thailand yang memiliki rata-rata skor 417.

Berbagai faktor dapat dipandang sebagai penyebab rendahnya mutu pendidikan khususnya pendidikan fisika. Salah satu faktor adalah proses pembelajaran. Berkaitan dengan proses pembelajaran fisika dewasa ini, tampak bahwa model pembelajaran yang dianut oleh para guru didasarkan pada asumsi tersembunyi bahwa pengetahuan dapat dipindahkan secara utuh dari pikiran guru ke pikiran siswa (Sadia, 1996). Karena itu, para guru memfokuskan diri pada upaya penuangan pengetahuan ke kepala siswanya. Dalam keadaan demikian mungkin guru sudah merasa mengajar dengan baik, namun para siswanya tidak belajar dalam arti tidak terjadi perkembangan struktur kognitif pada pebelajar.

Banyak penelitian (misalnya Osborne \& Wittrock, 1983; Sadia 1996; Suma, 1994, 1997, 1998, 2002; Subratha, 2003)) menunjukkan bahwa siswa memasuki kelompok telah memiliki gagasan-gagasan/ide-ide tentang fisika. Gagasan/ide-ide itu umumnya dikembangkan dari pengalaman sehari-hari (Alwan, 2011), dan masih berlabel miskonsepsi. Miskonsepsi yang dibawa siswa bertentangan dengan penjelasan ilmiah (Broughton, Sinatra, \& Reynolds, 2010), bersifat resisten untuk diubah, tidak mudah diubah dengan pengajaran tradisional (Sungur, Tekkaya, \& Geban, 2001). Özkan \& Selçuk (2013) menyatakan bahwa miskonsepsi merupakan salah satu faktor penyebab kegagalan siswa dalam belajar fisika. Pengajaran tradisional tidak mempertimbangkan miskonsepsi yang dibawa ke kelompok. Pengajaran yang tidak mempertimbangkan miskonsepsi 
siswa tidak efektif dan tidak bermakna (Smith, Blakeslee \& Anderson dalam Önder \& Geban, 2006). Jika ide-ide siswa berbeda dengan definisi yang diterima oleh saintis, siswa tidak akan mampu membentuk link atau asosiasi antara pengetahuan baru dan pengetahuan awalnya.

Beberapa strategi yang berbasis pada strategi pengubahan konsep telah dilakukan untuk mengatasi miskonsepsi siswa. Salah satu dari strategi pengubahan konseptual adalah strategi yang berbasis teks. Sampai saat ini buku teks masih merupakan komponen yang esensial dalam pembelajaran sains. Kebanyakan buku teks sains/fisika dirancang dengan format teks berupa teks ekspositori (expository text) yang merupakan ensiklopedi pengetahuan. Suma (2011) dalam penelitian pengembangan mutu pendidikan mendapatkan bahwa bahan ajar yang dominan digunakan guru fisika dalam pembelajaran adalah buku-buku yang bersifat resep, yang berisi kumpulan rumus-rumus dan latihan soal. Buku-buku tersebut lebih mengarahkan siswa untuk menghafalkan rumus-rumus dan menggunakannya dalam memecahkan soal-soal darpada pengembangan pemahaman konsep dan prinsip-prinsip penting. Buku-buku teks fisika yang dianjurkan oleh kementerian pendidikan nasional juga masih bersifat ekspositori yang lebih banyak merupakan ensiklopedi pengetahuan. Belum dijumpai buku teks yang berbasis kepada pengubahan konseptual.

Dalam kaitan dengan upaya menanggulangi miskonsepsi siswa para peneliti mengadaptasi buku teks ekpositori untuk menciptakan format teks alternatif yang dipandang lebih efektif. Ada dua jenis format teks yang berbasis model pengubahan konsep yang telah diusulkan oleh Posner, Strike, Hewson, \& Gertzog (1982) yaitu teks pengubahan konsep (conceptual cahange text) dan teks sangkalan (refutation text). Teks sangkalan adalah teks khusus yang muncul dari model pengubahan konsep (conceptual change model) yang diusulkan oleh Posner, Strike, Hewson, \& Gertzog (1982). Teks sangkalan, kadangkadang disebut sebagai refutational text, adalah teks yang secara langsung ditujukan pada miskonsepsi, secara eksplisit kontradiktif dan menolak miskonsepsi itu dengan menjelaskan mengapa miskonsepsi itu secara ilmiah tidak dapat diterima, dan kemudian menyajikan eksplansi ilmiah tentang konsep tersebut.

Teks sangkalan terdiri atas tiga unsur yaitu (1) penyajian miskonsepsi, (2) penyajian sangkalan secara implisit terhadap miskonsepsi tersebut, dan (3) penyajian konsep yang dapat diterima secara ilmiah. Dengan gaya semacam ini diharapkan terjadinya konflik kognitif pada siswa yang dicirikan oleh adaya: pengakuan terhadap situasi anomali, ketertarikan terhadap situasi anomali, kegelisahantehadap situasi anomali, dan penilaian kembali terhadap situasi anomali (Lee et al., 2003).

Riset-riset mengenai teks sangkalan didasarkan pada teori konstruktivisme yang menekankan kepada peran aktif pebelajar dalam memperoleh keterampilan dan pengetahuan (Guzetti, Snyder, Glass, \& Gamas, 1993). Dua perspektif kostruktivisme yang dominan adalah konstruktivisme kognitif dan 
kostruktivisme sosial. Konstruktivisme kognitif mengacu kepada pemikiran Piaget, yang menekankan bahwa pengetahuan dibangun melalui pengalaman personal. Sementara itu, perspektif konstruktivisme sosial mengacu kepada pemikiran Vygotsky yang menekankan hakikat sosial dari pengalaman.

\section{Menurut}

perspektif

kostruktivisme, pengetahuan awal yang dimiliki oleh pebelajar secara alamiah akan mempengaruhi perolehan pegetahuan baru dari buku teks. Ada beberapa faktor yang mempengaruhi apakah terjadi perubahan konsep atau tidak ketika pembaca dihadapkan pada informasi baru. Faktor-faktor tersebut mencakup struktur dan akurasi pengetahuan awal (prior knowledge) siswa, dan juga keberadaan dan ketiadaan kondisi-kondisi yang diperlukan untuk terjadinya pengubahan konsep.

Penelitian ini bertujuan untuk menguji keefektifan penerapan teks-teks sangkalan terhadap pengubahan miskonsepsi siwa dan penguasaan konsep siswa tentang hukum I dan III Newton.Pertanyaan-pertanyaan

penelitian yang dijawab dalam penelitian ini adalah: (1) bagaimana efektivitas teks-teks sangkalan dalam mengubah miskonsepsi siswa tentang hukum I dan III Newton? (2) seberapa besar persentrase siswa yang memiliki konsep ilmiah, (3) apakah terdapat perbedaan penguasaan konsep hukumNewton I dan III antara siswa yang diajar dengan menggunakan teks sangkalan dan yang diajar dengan menggunakan teks tradisional?

\section{METODE}

Penelitian ini merupakan penelitian kuasi eksperimen dengan desain pre-tet, post-test non equivalen control group design seperti berikut.Kelompok eksperimen $\mathrm{O} 1 \mathrm{X}$

\section{$\mathrm{O} 2$}

Kelompok kontrol $01 \quad-\quad 02$ $\mathrm{O} 1=$ oservasi awal, $\mathrm{O} 2$ = observasi akhir, $\quad \mathrm{X}=$ perlakuan berupa pembelajaran dengan teks sangkalan.

Populasi penelitian ini adalah siswa-jurusan IPA kelompok $X$ di SMA Negeri di Kota Singaraja. Di kota Singaraja terdapat empat SMAN yaitu SMA N 1, SMA N 2, SMA N 3, dan SMA $\mathrm{N} 4$ Singaraja. Penetapan sampel kelompok pada masing-masing sekolah dilakukan dengan teknik random kelompok. Dalam penelitian ini ditetapkan tiga SMA sebagai sampel penelitian yaitu SMA N 1 Singaraja, SMA Negeri 2 dan SMA Negeri 3 Singaraja. Pertimbangan penetapan SMA ini adalah berdasarkan lokasinya. SMA Negeri 1 adalah SMA di pusat kota, SMA Negeri 3 di kota tetapi bukan di pusat, SMA Negeri 2 adalah SMA denga lokasi perbatasan desa dan kota. Sampel siswa dari masing-masing sekolah ditetapkan dengan sampel kelompok. Dari jumlah kelompok yang ada pada masing-masing sekolah ditetapkan satu kelompok ekepserimen dan satu kelompok kontrol. Berdasarkan teknik sampling yang dilakukan diperoleh jumlah siswa kelompok eksperimen dan kontrol seperti pada Tabel 1. Kelompok eksperimen adalah kelompok yang mendapatkan pembelajaran hukum I dan III Newton menggunakan teks sangkalan.Kelompok kontrol adalah kelompok siswa yang mendapatkan 
pembelajaran menggunakan teks ekpositori/teks tradisional.

Data yang dikumpukan dalam penelitian ini adalah peningkatan penguasaan konsep siswa tentang hukum I dan III Newton dan peningkatan persentase siswa yang meiliki konsep ilmiah dapat dilihat pada tabel 1 .

Tabel 1. Jumlah Kelompok Kontrol dan Eksperimen

\begin{tabular}{ccc}
\hline Nama Sampel SMA & $\begin{array}{c}\text { Jumlah klp } \\
\text { ekperimen }\end{array}$ & $\begin{array}{c}\text { Jumlah } \\
\text { klp kontrol }\end{array}$ \\
\hline 1. SMA Negeri 1 Singaraja & 30 & 30 \\
2. SMA Negeri 2 Singaraja & 21 & 36 \\
3. SMA Negeri 3 Singaraja & 22 & 19 \\
\hline Jumlah & 73 & 85 \\
\hline
\end{tabular}

Data dikumpulkan dengan teknik tes. Instrumen yang digunakanuntuk pengumpulan data penguasaan konsep siswa adalah tes pemahaman konsep yang terdiri atas konsep-konsep hukum I dan III Newton. Tes ini berbentuk pilihan ganda yangterdiri atas 20 item. Tes ini memiliki indek reliabilitas $r=0,65$.

Data tentang penguasaan konsep hukum I dan III Newton dan penurunan persentase siswa yang mengalami miskonsepsi dianalisis dengan teknik deskriptif. Efektivitas pembelajaran diukur dengan menghitung peningkatan penguasaan konsep siswa dari sebelum pembelajaran dan sesudah pembelajaran, dengan menghitung gain skor ternormalisasi g, dimana

$$
g=\frac{X_{p o s t}-X_{p r e}}{X_{m a k}-X_{p r e}}(\text { Hake, 1998) }
$$

Rumus ini juga digunakan untuk mengatasi ketidaksetaraan sampel antara kelompok eksperimen dan kelompok kontrol.Kriteria keefektifan pembelajaran dilihat dari $\mathrm{g}$ rata-rata dikategorikan menjadi tiga kategori yaitu tinggi, sedang, dan rendah seperti berikut.

$$
\begin{array}{ll}
\bar{g} \geq 0,7 & \text { Tinggi } \\
0,3 \leq \bar{g}<0,7 & \text { Sedang } \\
\bar{g}<0,3 & \text { Rendah }
\end{array}
$$

Untuk membandingkan peningkatan penguasaan konsep siswa kelompok eksperimen dan kelompok kontrol data dianalisis dengan uji statistk nonparametric yaitu Uji Mann Whitney $\mathrm{U}$, dengan taraf signifikansi 0,05.

\section{HASIL DAN PEMBAHASAN}

Tabel 2 menunjukkan ringkasan statitik deskriptif gains skor kelompok eksprimen dankelompokkontrol.Dari Tabel 2 tampak rata-rata gain skor kelompok ekperimen $\bar{g}=0,54$ dengan $\mathrm{SD}=0,128$. Dilihat dari kriteria keefektifan pembelajaran, pembelajaran yang diberikan pada kelompok ekpserimen yakni pembelajaran dengan teks sangkalan ternasuk dalam keefektifan sedang. Sementara itu, ratarata $g$ siswa kelompok kontrol adalah $\bar{g}=0,16, \mathrm{SD}=0,104$. Dilihat dari kriteria keefektifan pembelajaran, pembelajaran pada kelompok kontrol yang 
menggunakan teks ekspositori termasuk dalam keefektifan rendah. Membandingkan rata-rata gains skor kelompok kontrol dan eksperimen tampak secara kualifikasi pembelajaran pada kelompok eksperimen lebih efektif daripada pembelajaran kelompok kontrol.

Jadi, pembelajaran yang menggunakan teks sangkalan lebih efektif daripada yang menggunakan teks ekspositori dalam meningkatkan penguasaan konsep siswa dapat dilihat pada table 2.

Tabel 2. Ringkasan Analisis Deskriptif Gain Skor Kelompok Eksperimen dan Control

\begin{tabular}{cccccc}
\hline kelompok & $\mathbf{N}$ & $\mathbf{g}$ min & G mak & Mean $\mathbf{~}$ & SD \\
\hline eksperimen & 73 & 0,18 & 0,80 & 0,54 & 0,128 \\
Kontrol & 85 & 0,00 & 0,50 & 0,16 & 0,104 \\
\hline
\end{tabular}

gains 1

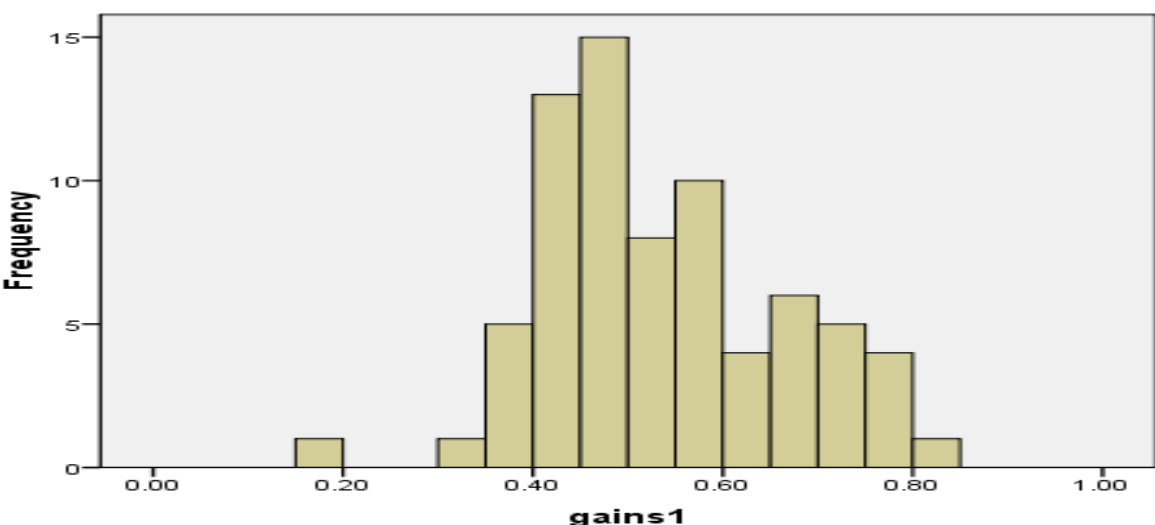

Mean $=0.54$
Std. Dev $=0.128$
$N=73$

Gambar 1 Histogram distribusi frekuensi gain skor kelompok eksperimen (gainseks)

Dari gambar 1 tampak bahwa gains skor siswa sangat variatif, walaupun masih ada 1 orang siswa memperoleh gain skor di bawah 0,3 , namun sebagian besar mendapatkan gain skor diatas 0,3 .

Frekuensi terbesar siswa tampak pada perolehan gain skor ternormalisasi antara 0,5 dan 0,6 yang berada dalam kategori sedang. Ini menunjukkan bahwa pengajaran hukum I dan III Newton dengan menggunakan teks sangkalan cukup efektif untuk meningkatkan pemahaman konsep siswa.

Gambar 2 menunjukkan histogram gain skor ternormalisasi kelompok kontrol. Tampak bahwa frekuensi terbesar siswa pada perolehan gain skor 0,20. 


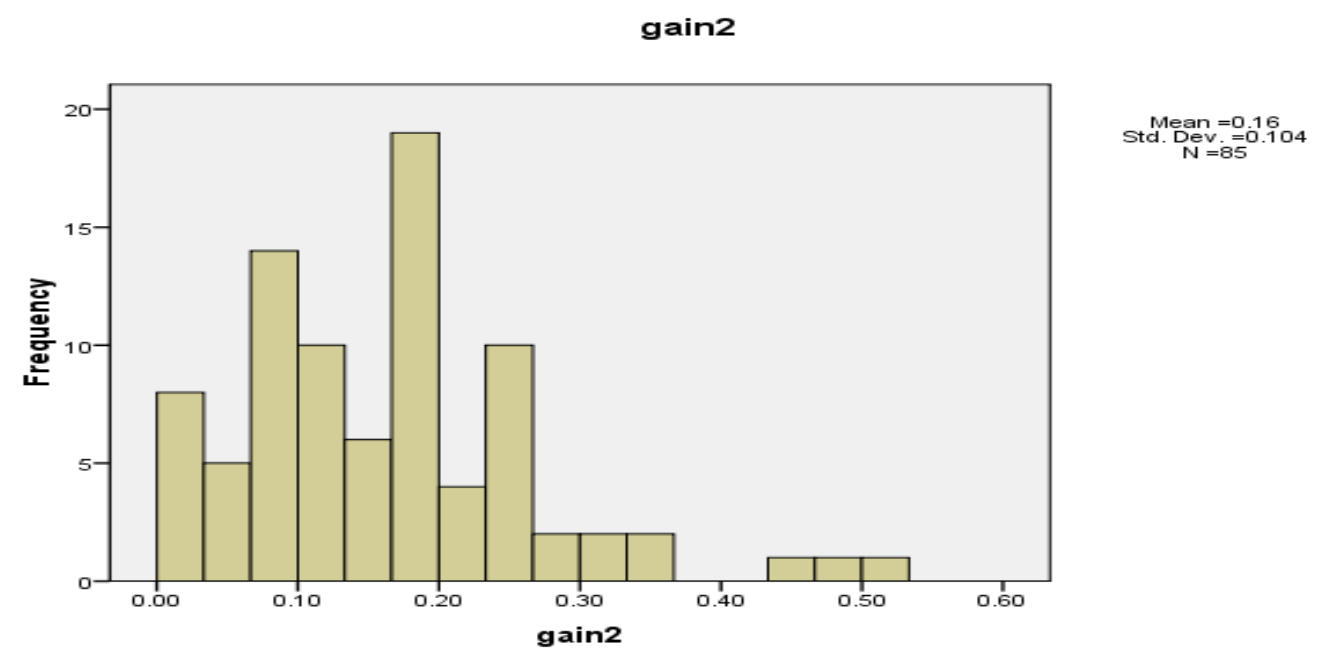

Gambar 2 Distribusi frekuensi gains skor siswa kelompok kontrol (gainkont)

Tanpak pula bahwa sebagian besar siswa cenderung memperoleh gain skor rendah. Dengan demikian, dapat dinyatakan bahwa pembelajaran hukum I dan III Newton dengan menggunakan teks ekspositori kurang efektif untuk meningkatkan penguasaan konsep siswa.
Gambar 3 menunjukkan histogram persentase siswa kelompok eksperimen yang memiliki konsep ilmiah sebelum dan sesudah pembelajaran serta persentase kenaikannya.

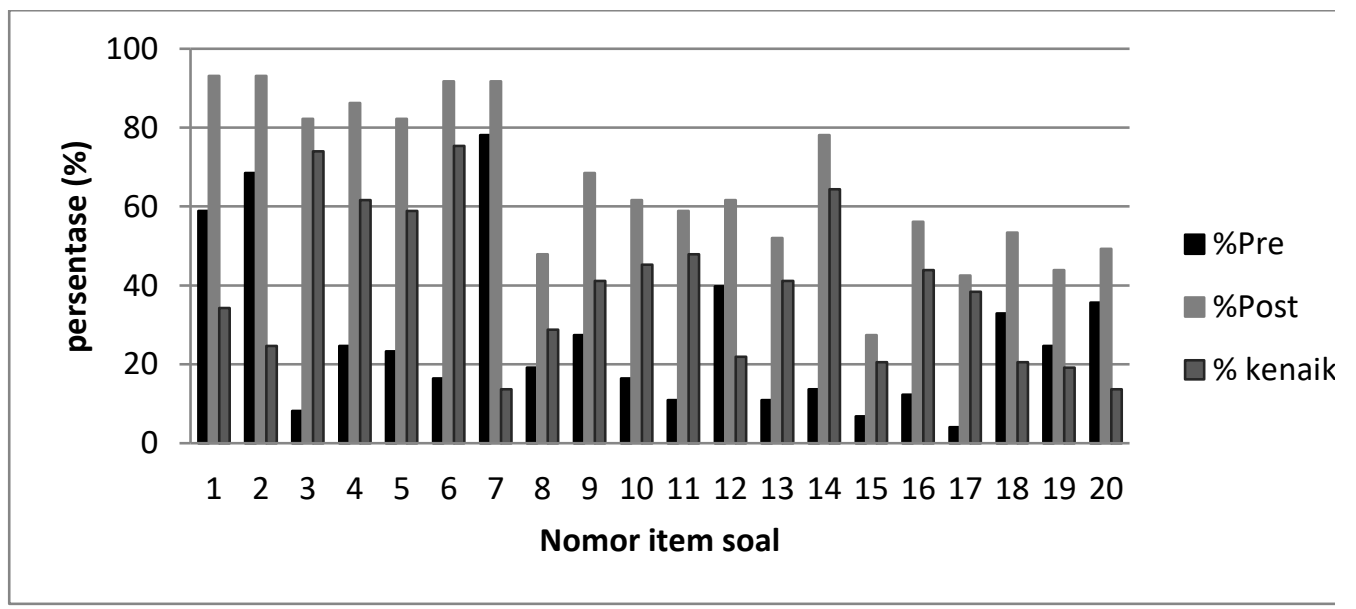

Gambar 3. Persentase kelompok eksperimen yang memiliki konsep ilmiah

Dari gambar 3 tampak bahwa Secara umum persentase siswa yang menguasai hukum I Newton (item nomor 1 sampai dengan 12) lebih tinggi 
dari pada yang menguasai konsepkonsep hukum III Newton (item nomor 13 s.d 20). Terdapat 8 item tes yang dikuasi oleh lebih dari $70 \%$ siswa yaitu item no 1,2,3,4,5,6,7 dan 14.

Demikian pula kenaikan persentase siswa yang menguasai konsep-konsep hukum I Newton secara umum lebih tinggi daripada perubahan persentase yang menguasai hukum III Newton.
Gambar 4 menunjukkan presentase siswa kelompok kontrol yang menguasai konsep-konsep hukum I Newton dan hukum III Newton. Dari gambar 4, tampak bahwa hanya 3 item soal yang dikuasai oleh $\geq 70 \%$ siswa kelompok kontrol yaitu item no 1, 2 dan 12. Secara umum persentase siswa kelompok kontrol yang menguasai konsep-konsep hukum I Newton lebih tinggi dari yang menguasai konsepkonsep tentang hukum III Newton.

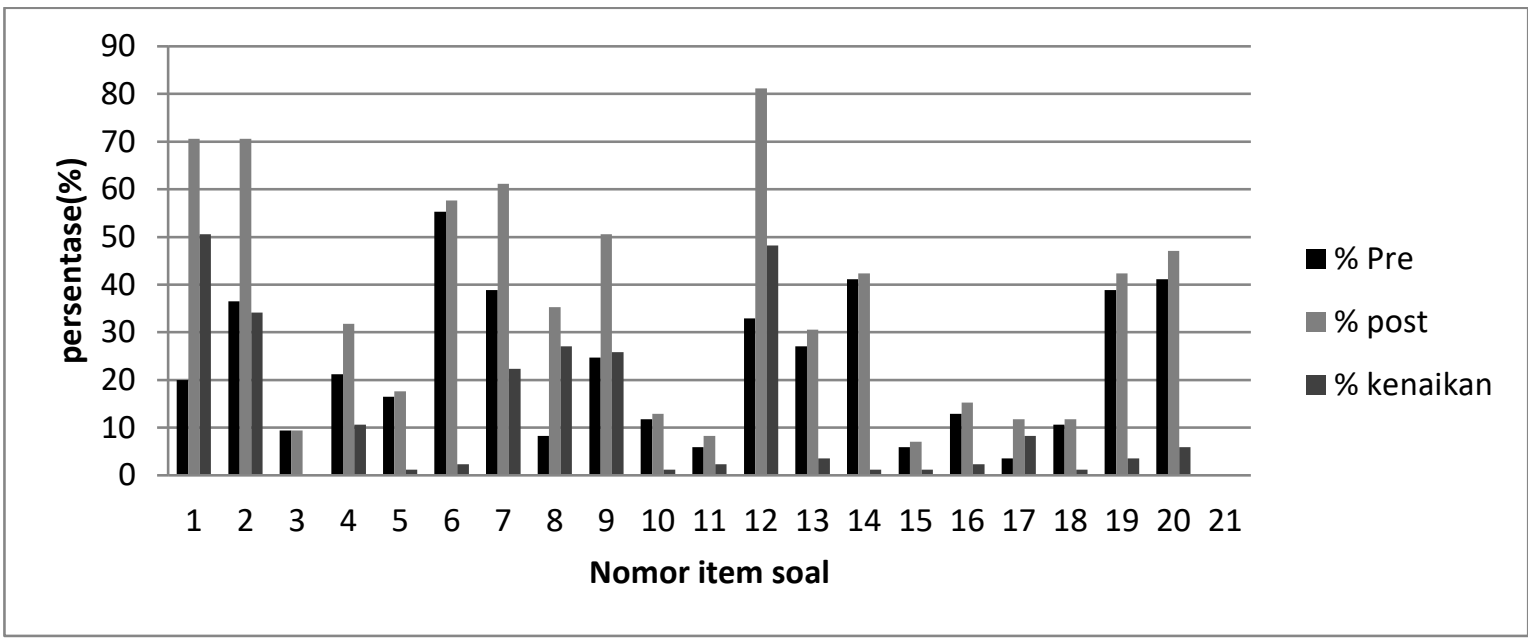

Gambar 4. Persentase kelompok kontrol yang memiliki konsep ilmiah

Hipotesis yang diuji dalam penelitian ini adalah Ho: tidak terdapat perbedaan peningkatan penguasaan konsep antara kelompok eksperimen dan kelompok kontrol. H1: terdapat perbedaan peningkatan penguasaan konsep antara kelompok ekperimen dan kelompok kontrol.

Mengingat sebaran data gain skor kelompok eksperimen berdistribusi normal sedangkan data kelompok kontrol tidak berdistribusi normal, maka untuk menguji signifikansi perbedaan penguasaan konsep kelompok ekeperimen dan kelompok kontrol digunakan uji statistik nonparametric. Uji nonparametric yang digunakan adalah Uji Mann-Whitney U. Tabel 2.a dan 2.b menunjukkan ringkasan hasil Uji MannWhitney U. 
Tabel 2a. Rank Kelompok Eksperimen dan Kontrol

\begin{tabular}{cccc}
\hline Kelompok & $\mathbf{N}$ & Mean Rank & Sum of rankg \\
\hline 1 & 73 & 116,56 & 8509,00 \\
2 & 85 & 47,67 & 4052,00 \\
Total & 158 & & \\
\hline
\end{tabular}

Dari Tabel 2.a tampak bahwa mean rankkelompok eksperimen $=116,56$, dan sum of rank $=8509,00$. Sementara itu, mean rankkelompok kontrol adalah 47,67 dan sum of ranknya adalah $=$ 4052,00. Tabel 2.b menunjukkan ringkasan hasil uji Mann-Whitney U. Tampak bahwa nilai $Z=-9,441$ dengan signifikansi $p<0,05$. Dari Tabel 3.b tampak bahwa nilai Mann-Whitney $U$ adalah 397,000 dengan signifikansi $p<0,05$.

Tabel 2.b Test Statistics ${ }^{a}$ Kelompok Eksperimen dan Control

\begin{tabular}{lc}
\hline Variasi Statistik & gain12 \\
\hline Mann-Whitney U & 397,000 \\
Wilcoxon W & $4,052 \mathrm{E} 3$ \\
Z & $-9,441$ \\
Asymp. Sig. (2-tailed) & 0,000 \\
\hline
\end{tabular}

a. Grouping Variable: klp

Hal ini menunjukkan bahwa hipotesis nol ditolak dan dapat disimpulkan bahwa terdapat perbedaan peningkatan penguasaan konsep antara siswa kelompok ekperimen dan kelompok kontrol.Kelompok eksperimen adalah kelompok siswa yang mendapat pembelajaran dengan teks sangkalan, sedangkan kelompok kontrol adalah kelompok yang dibelajarkan dengan teks ekspositori. Jadi, dapat disimpulkan bahwa penggunaan teks sangkalan lebih efektif daripada teks tradisional dalam meningkatkan penguasaan konsep siswa. Tingkat penguasaan konsep siswa berhubungan dengan tingkat miskonsepsi siswa, makin tnggi penguasaan konsep siswa makin rendah kadar miskonsepsi yang dimiliki oleh siswa. Ini berarti pula bahwa teks sangkalan lebih efektif daripada teks tradisional sebagai strategi pengubahan konsep. Walaupun uji Mann-Whitney tidak membedakan skor rata-rata antara kelompok eksperimen dan kelompok kontrol, namun statistik deskriptif menunjukkan rata-rata gain skor kelompok eksperimen lebih besar dari pada rata-rata gain skor kelompok kontrol.

Hasil penelitian menunjukkan bahwa rata-rata gains kelompok eksperimen $\bar{g}=0,55$ dengan $\mathrm{SD}=0,15$. yang menunjukkan bahwa efektivitas pembelajaran dengan teks sangkalan termasuk dalam kategori sedang. Sementara itu, rata-rata gain skor ternormalisasi $\bar{g}$ kelompok kontrol adalah $\quad \bar{g}=0,21, \quad S D=0,18 \quad$ yang menunjukkan bahwa efektivitas 
pembelajaran pada kelompok kontrol termasuk dalam kategori rendah. Dibandingkan dengan rata-rata gain skor kelompok kontrol, rata-rata gains skor kelompok ekperimen lebih tinggi daripada kelompok kontrol. Ini menunjukkan teks sangkalan lebih efektif daripada teks tradisional dalam meningkatkan penguasaan konsep siswa tentang hukum I dan hukum III Newton.

Walaupun penentuan kelompok ekeperimen dan kelompok kontrol dalam penelitian ini dilakukan melalui sampling kelompok dalam arti menggunakan kelompok-kelompok utuh, penguasaan konsep awal siswa dapat dipandang tidak menyebabkan terjadinya perbedaan rata-rata gain skor kedua kelompok. Perbedaan kemampuan awal yang mungkin ada telah direduksi dengan menggunakan rumus gain skor ternormalisasi. Dengan demikian, secara deskriptif perbedaan rata-rata gains skor ternormalisasi antara kelompok eksperimen dan kontrol dapat mencerminkan perbedaan keefektifan pengajaran dengan menggunakan teks sangkalan dan yang menggunakan teks tradisional.

Secara umum rata-rata persentase siswa kelompok eksperimen yang memiliki konsep ilmiah tentang hukum I dan III Newton lebih tinggi daripadakelompok kontrol. Penggunaan teks sangkalan dapat meningkatkan jumlah siswa yang memiliki konsep ilmiah rata-rata $39,45 \%$, sedangkan penggunaan teks tradisional hanya dapat meningkatkan jumlah siswa yang memiliki konsep ilmiah rata-rata $12,65 \%$. Terdapat 8 item tes yang dikuasi oleh lebih dari $70 \%$ siswa yaitu item no $1,2,3,4,5,6,7$ dan 14 , sementara itu hanya tiga item tes yang dkuasai oleh lebih dari $70 \%$ siswa kelompok control, yaitu item 1,2 dan 12. Penggunaan teks sangkalan lebih efektif dalam meningkatkan jumlah siswa yang memiliki konsep ilmiah daripada teks tradisional. Baik pada kelompok eksperimen maupun pada kelompok kontrol persentase siswa yang memiliki konsep ilmiah hukum I newton lebih tinggi daripada konsep hukum III Newton.

Tampak adanya konsistensi antara tingkat penguasaan konsep siswa dengan persentase siswa yang memiliki konsep ilmiah. Kelompok siswa yang memiliki rata-rata gain skor ternormalisasi lebih tinggi cenderung memiliki konsep ilmiah lebih tinggi pula, demikian sebaliknya. Hal ini dapat terjadi karena skor penguasaan konsep siswa dihitung dari jawaban benar siswa. Berarti semakin besar skor siswa semakin banyak soal yang dijawab benar. Jawaban benar terhadap suatu soal menunjukkan penguasaan siswa terhadap konsep-konsep yang ditanyakan dalam soal.

Uji Mann Whitney U menujukkan bahwa terdapat perbedaan peningkatan penguasaan konsep antara siswa kelompok ekeprimen dan kelompok kontrol. Ini berarti jumlah siswa yang mendapatkan peningkatan penguasaan konsep diukur dengan nilai gain skor ternormaliassi. Secara deskriptif tampak bahwa rata-rata gain skor ternormalisasi kelompok ekperimen lebih tinggi daripadakelompok kontrol.

Dilihat dari skenario pembelajaran dari phase pelibatan siswa sampai pada explanasi/demonstrasi kedua kelompok ini mendapat perlakukan yang sama. 
Jenis eksplanasi dan demonstrasipun sama. Perbedaan perlakuan yang diberikan adalah pada tahap review dan pendalaman. Pada tahap review, kelompok eksperimen ditugasimembaca teks sangkalan, dan kelompok kontrol ditugasi membaca teks ekspositori yang biasa digunakan dalam pembelajaran di sekolah. Pada phase ini siswa dikontrol dengan ketat agar mereka benar-benar menggunakan waktunya untuk membaca teks yang ditugasi.

Bercermin dari skenario pembelajaranya yang dilakukan untuk kedua kelompok, dapat diyakini bahwa penyebab perbedaan gain skor rata-rata ternormlisasi antara dua kelompok disebabkan olehperbedaan teks yang digunakan. Walaupun sampel penelitian ini diambil atas dasar kelompok/ kelompok utuh yang mungkin memiliki perbedaan awal penguasaan konsep, namun pengaruh perbedaan awal ini sudah dieleminir dengan menggunakan gains skor ternormalisasi.

Berbeda dengan teks sangkalan, ekspositori lebih menekankan kepadaaspek matematika dan hitungan-hitungan, kurang memberi penjelasan terhadap fenomena alam yang berkaitan dengan konsep-konsep tersebut. Penjelasan yang diberikan pada teks-teks ekspositori umumnya sangat singkat, sehingga siswa kurang mendapatkan informasi untuk mengatasi atau memodifikasi miskonsepsi yang mereka bawa atau dapatkan dari berbagai sumber. Penjelasan yang singkat ini menyebabkan siswa tidak terlatih untuk membaca teks dan menganalisis suatu masalah. Siswa cenderung menghindari membaca penjelasan yang ada pada buku, tetapi lebih kepada mencari rumus-rumus kemudian mencoba soal-soal untuk menggunakan rumus tersebut. Demikian pula soal-soal latihan yang terdapat dalam buku teks tradisional, kurang dilengkapi dengan pertanyaanpertanyaan yang bersifat konseptual.

Teks sangkalan cukup menyediakan kondisi-kondisi untuk terjadinya perubahan konsep pada siswa, karenateks sangkalan diawali oleh penyajian miskonsepsi siswa berkaitan dengan konsep yang dibahas, kemudian disertai dengan sangkalan dan argumentasi-argumentasi tentang sangkalan itu. Teks ini juga dilengkapi dengan contoh-contoh konkret untuk memperjelas argumentasi-argumentasi dimaksud. Argumentasi dan contohcontoh yang disajikan teks ini dapat meyakinkan siswa bahwa miskonsepsi yang disajikan atau yang mereka bawa memang tidak sesuai dengan konsep ilmiah dan fenomena yang ada. Hal ini akan menimbulkan konflik kognitif pada diri siswa, yang pada akhirnya mereka akan secara sadar mengubah pandangan/gagasan-gagasannya atau konsepsi awal mereka. Pada akhir setiap teks disediakan latihan-latihan yang bersifat konseptual yang bertujuan untuk memperdalam pemahaman konsep mereka.

Terdapat beberapa penelitian yang koheren dengan hasil penlitian ini yang menunjukkan bahwa penggunaan teks sangkalan lebih efektif daripada teks ekspositori dalam menanggulangi miskonsepsi siswa. Çetingul \& Geban (2011) menunjukkan bahwa penggunaan teks pengubahan konsep dengan analogi menyebabkan perolehan konsep ilmiah dan eliminasi miskonsepsi lebih baik daripada pembelajaran konvensional. Guzetti et 
al. (1993) menunjukkan bahwa teks sangkalan (refutation text) efektif untuk memfasilitasi pengubahan konsep. Toka dan Askar (2002) mendapatkan bahwa skor matematik siswa yang diajar dengan strategi konflik kognitif dan teks pengubahan konsep secara signifikan lebih tinggi daripada siswa yang diajar dengan statgei konvensional.

Studi yang dilakukan oleh Önder \& Geban (2006) menunjukkan bahwa pengajaran yang berbasis pengubahan konsep yang menggunakan teks pengubahan konseptual lebih baik daripada pengajaran dengan metode tradisional dalam meremidiasi miskonsepsi siswa dan meningktkan pemahaman siswa terhadap konsep kesetimbangan daya larut. Broughton et al. (2010) menunjukkan bahwa pembaca memerlukan waktu lebih sedikit untuk membaca paragraph pada teks sangkalan dibandingkan dengan paragraph pada teks ekspositori. Kelompok yang menggunakan teks sangkalan menunjukkan sedikit miskonsepsi pada post-test. Namun demikian, terdapat pula penelitianpenelitian (seperti: Palmer, 2003) yang menunjukkan bahwa teks sangkalan tidak lebih efektif daripada teks ekspositori dalam menanggulangi miskonsepsi siswa.

\section{SIMPULAN DAN SARAN}

Penggunaan teks sangkalan pada pembelajaran fisika efektif dalam meningkatkan penguasaan konsep siswa tentang hukum I Newton dan hukum III Newton dalam kategori sedang. Nilai rata-rata gain skor ternormalisasi (g) siswa yang belajar dengan teks sangkalan adalah 0,55 dengan $S D=0,15$, yang termasuk kategori sedang.

Penggunaan teks sangkalan dapat meningkatkan jumlah siswa yang memiliki konsep ilmiah rata-rata $39,45 \%$, sedangkan penggunaan teks tradisional hanya dapat meningkatkan jumlah siswa yang memiliki konsep ilmiah rata-rata $12,65 \%$. Penggunaan teks sangkalan lebih efektif dalam meningkatkan jumlah siswa yang memiliki konsep ilmiah daripada teks tradisional. Terdapat perbedaan peningkatan penguasaan konsep antara siswa yang belajar dengan teks sangkalan dan yang belajar dengan teks tradisional. Rata-rata gain skor ternormalisasi (g) siswa yang belajar dengan teks sangkalan lebih tinggi daripada siswa yang belajar dengan teks tradisional.

Pengembangan teks-teks sangkalan dapat dilakukan dengan memodifiksi teks-teks tradisional, memperkayanya dengan paparan akan pentingnya konsep-konsep yang akan dibahas, sajian miskosnepsi, sangkalan terhadap miskonsepsi tersebut disertai dengan argumentasi dan contoh-contoh fenomema yang berkaitan dengan konsep itu, dan bagian terakhir berisikan latihan-latihan konseptual.Teks-teks sangkalan yang dikembangkan dalam penelitian ini dapat dipertimbangkan sebagai salah satu suplemen bahan ajar untuk memperkaya bahan ajar yang digunakan.Sebelum menerapkan teksteks sangkalan yang mengandung eksplansi argumentatif, guru perlu mengubah kebiasaan siswa dari membaca teks-teks ringkasan materi pelajaran atau kumpulan rumus-rumus dengan melatihnya membaca teks yang berisi eksplanasi untuk melatih penalaran dan berargumentasi. 


\section{DAFTAR PUSTAKA}

Alwan, A. A. (2011). Misconception of heat and temperature among physics students. Procedia-Social and Behavioral Sciences, 12, 600614.

Broughton, S. H., Sinatra, G. M., \& Reynolds, R. E. (2010). The nature of the refutation text effect: An investigation of attention allocation. The Journal of Educational Research, 103(6), 407-423.

Çetingul, I., \& Geban, Ö. (2011). Using conceptual change texts with analogies for misconceptions in acids and bases. H.U. Journal of Education, 41, 112-123.

Guzetti, B. J., Snyder, T. E., Glass, G. V, \& Gamas, W. S. (1993). Metaanalysis of instructional interventions from reading education and science education to promote conceptual change in science. Reading Research Quarterly, 28(2), 116-161.

Hake, R. R. (1998). InteractiveEngagement vs. Traditional Methods: A Six-Thousand-Student Survey of Mechanics Test Data for Introductory Physics Courses. ERIC.

Lee, G., Kwon, J., Park, S.-S., Kim, J.W., Kwon, H.-G., \& Park, H.-K. (2003). Development of an instrument for measuring cognitive conflict in secondary-level science classes. Journal of Research in
Science Teaching, 40(6), 585-603.

Önder, I., \& Geban, Ö. (2006). The effect of conceptual change texts oriented instruction on students' understanding of the solubility equilibrium concept. H.U. Journal of Education, 30, 166-173.

Osborne, R. J., \& Wittrock, M. C. (1983). Learning science: A generative process. Science Education, 67(4), 489-508.

Özkan, G., \& Selçuk, G. S. (2013). The use of conceptual change texts as class material in the teaching of "sound" in physics. In Asia-Pacific Forum on Science Learning and Teaching (Vol. 14, pp. 1-22).

Palmer, D. H. (2003). Investigating the relationship between refutational text and conceptual change. Science Education, 87(5), 663684.

Posner, G. J., Strike, K. A., Hewson, P. W., \& Gertzog, W. A. (1982). Accommodation of a scientific conception: Toward a theory of conceptual change. Science Education, 66(2), 211-227.

Sungur, S., Tekkaya, C., \& Geban, Ö. (2001). The contribution of conceptual change texts accompanied by concept mapping to students' understanding of the human circulatory system. School Science and Mathematics, 101(2), 91-101. 